\title{
Comparative Effect of Different Commercial Herbal Growth Promotors on Performance, Minor Body Parts Weight and Immune Responce in Broilers
}

\author{
Sultan Mahmood ${ }^{1}$, Muhammad Furqan Saleem ${ }^{1}$, Fawwad Ahmad ${ }^{1}$, Ghulam Abbas ${ }^{1, *}$, Aisha Mahmood ${ }^{2}$, \\ Sajid Hussain Qamar' ${ }^{1}$, Muhammad Zia ur Rehman ${ }^{3}$ \\ ${ }^{1}$ Department of Poultry Science, University of agriculture, Faisalabad, Pakistan \\ ${ }^{2}$ Department of veterinary Physiology and Pharmacology, University of agriculture, Faisalabad, Pakistan \\ ${ }^{3}$ Department of Clinical medicine and surgery, University of agriculture, Faisalabad, Pakistan \\ *Corresponding Author: ghulamabbas_hashmi@yahoo.com
}

Copyright (C) 2014 Horizon Research Publishing All rights reserved.

\begin{abstract}
Antibiotics have been used in poultry to improve growth performance but due to their side effects European Union has banned use of antibiotic as growth promoters in animal feed in 2006. Such situations has resulted in search for natural and safe alternatives, therefore, this study was undertaken to compare the efficacy of commercial herbal growth promoter as dietary inclusion on performance, minor body parts weight and immune response in broiler. A total of 120 healthy day old Hubbard chicks of uniform body weight were divided into 12 experimental units of 10 chicks each. These experimental units were further allotted to 4 treatment groups $\left(\mathrm{T}_{1}, \mathrm{~T}_{2}, \mathrm{~T}_{3}\right.$ and $\left.\mathrm{T}_{4}\right)$ such that each treatment received 3 replicates. Group A was fed ration without supplementation of commercial herbal products i.e. control whereas group $\mathrm{B}, \mathrm{C}$ and $\mathrm{D}$ were fed ration supplemented with commercial herbal products i.e. Bio-Mix, Respecine and A one Formula respectively each @ 100 g/ 50 $\mathrm{kg}$ of commercial feed. Each experimental unit of the chicks was reared in a separate pen. The birds were kept under similar managerial conditions. Feed intake, weight gain and FCR was better in group $\mathrm{C}$ fed respecine supplemented diet $(\mathrm{P}<0.05)$ whilst immune response against ND and IBD was higher in group $\mathrm{B}$ fed diet supplemented with Bio-mix $(\mathrm{P}<0.05)$ whereas dressing percentage, liver weight, heart weight, gizzard weight, spleen weight, pancrease weight and intestinal weight were not significantly affected by commercial herbal growth promotors $(\mathrm{P}>0.05)$. Use of various commercial herbal growth promoters in the ration exhibited an increase in the profit margin of broilers. Broilers reared on respecine fetched maximum profit as compared to other groups.
\end{abstract}

Keywords Growth Promotors, Bio-Mix, Respecine, A One Formula, Broiler, Performance, Immune Response

\section{Introduction}

Poultry industry is continuously progressing through improvement of genetic potential of new broiler strains to provide high biological value protein for the human population [16]. Poultry meat is an important source of nutrients as it contains all the essential amino acid, essential long chain fatty acids, vitamins and minerals especially selenium, iodine, phosphorus, potassium, iron and zinc in desirable concentrations. The vitamins and minerals present in poultry meat help to boost the immune system, digestion and metabolism, strengthen bones and skin, build, maintain and repair body tissues.

Commercial poultry farming in Pakistan is challenged with many problems like Coccidiosis, salmonellosis etc. and huge losses due to pathogenic bacteria in feed which may cause poor weight gain or even increased mortality [23]. Antibiotic have been used in poultry for the past four decades to improve growth performance and the total use of antibiotics as a growth promoter is estimated to be 4500 tons per year provided by 137 million tons of poultry feed production however their usage in poultry industry is intensively controversial because of the development of bacterial resistance and potential consequence on human health $[8,15]$. European Union has banned use of antibiotic as growth promoters in animal feed in 2006. Such situations has resulted in search for natural and safe alternatives in form of prebiotic, probiotic, enzymes, herbal products, immune modulators, organic acid etc. to maintain optimum growth rates $[4,17]$.

As an alternative of antibiotic medicinal plants like garlic, ginger, kalongi, mint, neem, savory, sea-buckthorn and turmeric etc. are the most popular option for growth promoters [21]. Different parts of plants, their extracts viz. oil, leaves, bark, seed, roots and other vegetative parts etc. have been experimentally used in poultry as a growth 
promotor, antibacterial, anti coccidial, anti-parasitic, anti-fungal, anti-tumor, anti-cancer, pesticide, immune booster and immunogenic [28].

Certain herbal formulations have showed encouraging results reported significant improvement with respect to weight gain, feed efficiency, lowered mortality and increased livability in poultry $[18,3]$ as well as better resistance against feed contaminants like aflatoxin, drug [10].

Our country abounds in herbal wealth and innumerable plants of pharmacological properties therefore it is matter of interest to try some of our indigenous medicinal plants/herbs as commercial products. Thus the project has been planned to envisage the comparative efficacy of commercial herbal products: Bio - mix , Responcine and A-one formula on performance and immune response of broilers.

\section{Materials and Methods}

The experiment was conducted at Poultry Research Center, University of Agriculture, Faisalabad. One hundred twenty healthy day old Hubbard broiler chicks were divided into 12 experimental units having 10 chicks each. These experimental units were further allotted to 4 treatment groups $\left(T_{1}, T_{2}, T_{3}\right.$ and $\left.T_{4}\right)$ such that each treatment recieved 3 replicates. Group A was fed ration without supplementation of commercial herbal products i.e. control wherease group B, C and D were fed ration supplemented with commercial herbal products i.e. Bio-Mix, Respecine and A one Formula respectively each@100 g/ 50 kg of commercial feed. Duration of the trial was 40 days. Each experimental unit of the chicks was reared in a separate pen. The birds were kept under similar managemental conditions like space, light, temperature, ventilation and relative humidity. Fresh and clean water was available to the birds at all the times. All the birds will be vaccinated according to the recommended schedule.

Data on initial body weight, weekly body weight, weekly feed intake and mortality was collected. The data regarding feed intake and weight gain was used to calculate feed conversion ratio and growth rate of broilers. Immune response for each replicate was checked on 30-35 days of age. To find out the antibody titer against Newcastle disease and
Gumboro disease, a method described by Buxton and Fraser (1977)[7] was used. At the end of experiment two birds from each replicate was selected randomly and slaughtered for their carcass response and relative organ weight. Data on live weight, dressed weight, heart weight, gizzard weight, liver weight, spleen weight, pancreas weight and intestinal weight was also collected. At the end of experiment economics of each group was calculated. The data thus collected was subjected to statistical analysis using completely randomized design. The differences in the means were compared by least significance difference test [27].

\section{Results}

The mean values of the broiler performance kept on commercial feed without any supplementation (control) was taken as reference point for comparsion with other birds under different treatment i.e control, Bio - mix , Responcine and A-one formula. The average weight gain of broiler chicks in groups A, B, C and D was 1604, 1733, 1814 and $1695 \mathrm{~g}$, respectively (Table 1), during 42 days of experimental period (0-6 weeks of age). Statistical analysis of data exhibited that birds using ration supplemented with herbal growth promoters gained signicantly $(\mathrm{P}<0.05)$ more weight than those of control group. The highest weight gain was recorded in the birds of group $\mathrm{C}$ fed ration supplemented with respecine.

The mean values for feed consumption of the birds during the experimental period for freatment groups, A, B, C and D were 3487, 3477, 3636 and 3533g, respectively (Table 1). Statistical analysis of the data revealed that supplementation of herbal growth promoters in the broiler ration exhibited significant effects on the feed intake of the birds. Birds of groups $\mathrm{C}$ utilized feed more efficiently whereas poorest feed conversion ratio was observed in the birds of groups $\mathrm{A}$ (control).

Mean values for feed conversion ratio of the broiler in groups, A, B, C and D were 2.17, 2.00, 1.97 and 2.08, respectively. Difference in feed Conversion ratio was found to be significant $(\mathrm{P}<0.05)$. The birds of groups $\mathrm{C}$ (using ration supplemented with respecine) showed significantly better FCR.

Table 1. Final live weight, weight gain, fed consumption and feed conversion ratio of broiler fed different herbal grouth promoters from $0-42$ days.

\begin{tabular}{|c|c|c|c|c|}
\hline \multirow[b]{2}{*}{ Parameters } & \multicolumn{4}{|c|}{ Treatments } \\
\hline & $\begin{array}{c}\text { A } \\
\text { Control }\end{array}$ & $\begin{array}{c}\text { B } \\
\text { Bio-mix }\end{array}$ & $\begin{array}{c}\mathrm{C} \\
\text { respecine }\end{array}$ & $\begin{array}{c}\text { D } \\
\text { A-one Formula }\end{array}$ \\
\hline Initial weight (g) & 43.00 & 42 & 42.33 & 42.33 \\
\hline Final live weight (g) & 1647 & 1775 & 1856 & 1737 \\
\hline Weight gain $(\mathrm{g})$ & $1604^{\mathrm{c}} \pm 59.7$ & $1733^{\mathrm{ab}} \pm 38.4$ & $1814^{\mathrm{a}} \pm 43.4$ & $1695^{b} \pm 36.6$ \\
\hline Feed consumption $(\mathrm{g})$ & $3487^{c} \pm 99.4$ & $3477^{\mathrm{bc}} \pm 95.6$ & $3636^{\mathrm{a}} \pm 38.4$ & $3533^{c} \pm 10.2$ \\
\hline Feed conversion ratio ( $\mathrm{g}$ feed /g gain ) & $2.17^{\mathrm{c}} \pm 0.025$ & $2.00^{\mathrm{ab}} \pm 0.025$ & $1.97^{\mathrm{a}} \pm 0.012$ & $2.08^{b} \pm 0.015$ \\
\hline
\end{tabular}




\section{Dressing Percentage and Relative Organ Weight}

Statistical analysis of the data revealed that the supplementation of herbal grouth promoters in the broiler ration did not exibit any significant effect on the dressing percentage, liver weight, heart weight, gizzed weight, spleen weight, pancreas weight and intestinal weight of the experimental birds (table 2).

\section{Immune Response}

The results of the study revealed signigicant $(\mathrm{P}<0.05)$ effect of commercial herbal growth promoters on the immune response of broilers. Antibody titer against ND at $30^{\text {th }}$ day of age was maximum in-groups B (873.33) followed by groupD (783.33), A (558.33) and control, respectively. Analysis of variance of the data showed significant differences among the treatment groups with respect to antibody titer at $30^{\text {th }}$ day of age (Table 3 ). The maximum value for antibody against IBD titer was recorded in the birds of group $\mathrm{C}$ fed ration supplemented with Respecine which was 1030 , followed by those using Bio-mix (873.33), A-one formula (770) and control (470), repectively.

\section{Mortality}

The total number of birds died during the experiment were four i.e. two in group A, one in group B and one in group D. Percent mortality in group A, B, and D was $6.66 \%, 3.33 \%$ and $3.33 \%$ respectively. Whereas, no mortality was recorded in group C. Overall mortality percentage was found to be $3.33 \%$ during the experimental period. The postmortem findings of all the dead birds revealed that reason of mortality was heat stress because of electric failure.

\section{Economics}

The average cost of production per broiler kept under different treatment groups A, B, C, and D was Rs. 68.98, 68.84. 71.00 and 69.65, respectively (Table 4) excluding the cost of labour. Miscellaneous cost summed up Rs. 10/broiler, which included the estimated cost of electricity, gas , litter, disinfectants, vaccination and medication. The average live weight gain of broiler chicks in groups A, B, C, and D was $1.604,1.733,1.813$, and $1.694 \mathrm{Kg}$, respectively. The broilers were sold on live weight basis at the rate of Rs. 42.00 per Kg. The net profit per bird was found to be Rs. 0.32, 5.92, 6.70, and 3.01 in the respective treatments excluding the cost of labour. Net profit on per bird basis was more from the birds fed ration supplemented with Respecine followd by Bio-mix, A-one formula, and Control, respectively.

Table. 2. verage values of dressing percentages, relative giblet weights (g organ wt. /100g body wt.) pancrease and ingestinal of broilers fed difference herbal growth promoters from $0-42$ days

\begin{tabular}{|c|c|c|c|c|}
\hline \multirow{2}{*}{ Parameters } & \multicolumn{5}{|c|}{ Treatments } \\
\cline { 2 - 5 } & $\begin{array}{c}\text { A } \\
\text { Control }\end{array}$ & $\begin{array}{c}\text { B } \\
\text { Bio-mix }\end{array}$ & $\begin{array}{c}\text { C } \\
\text { respecine }\end{array}$ & $\begin{array}{c}\text { D } \\
\text { A-one Formula }\end{array}$ \\
\hline Dressing percentage & $61.04 \pm 4.5$ & $62.15 \pm 4.5$ & $62.18 \pm 4.56$ & $61.39 \pm 4.5$ \\
\hline Liver weight & $1.88 \pm 0.018$ & $1.64 \pm 0.018$ & $2.16 \pm 0.019$ & $0.45 \pm 0.0066$ \\
\hline Heart weight & $0.39 \pm 0.0066$ & $0.42 \pm 0.0066$ & $0.41 \pm 0.0066$ & $1.48 \pm 0.012$ \\
\hline Gizzard weight & $1.53 \pm 0.014$ & $1.64 \pm 0.014$ & $1.54 \pm 0.014$ & $0.10 \pm 0.005$ \\
\hline Spleen weight & $0.10 \pm 0.005$ & $0.11 \pm 0.0052$ & $0.10 \pm 0.005$ & $0.19 \pm 0.02$ \\
\hline Pancrease weight & $0.21 \pm 0.01$ & $0.17 \pm 0.008$ & $0.20 \pm 0.01$ & $3.25 \pm 0.032$ \\
\hline Intestinal weight & $3.27 \pm 0.032$ & $3.28 \pm 0.032$ & $3.53 \pm 0.032$ & \\
\hline
\end{tabular}

NS $=$ Non significant

Table 3. Mean values of antibody titer against Newcastle disease (ND) and infections disease (IBD) fed different herbal growth promoters from 0-42 days

\begin{tabular}{|c|c|c|c|c|}
\hline \multirow{2}{*}{ Parameters } & \multicolumn{4}{|c|}{ Treatments } \\
\cline { 2 - 5 } & $\begin{array}{c}\text { A } \\
\text { Control }\end{array}$ & $\begin{array}{c}\text { B } \\
\text { Bio-mix }\end{array}$ & $\begin{array}{c}\text { C } \\
\text { Respecine }\end{array}$ & $\begin{array}{c}\text { D } \\
\text { A-One Formula }\end{array}$ \\
\hline ND Antibody titer & $558.33^{\mathrm{d}} \pm 25.7$ & $873.33^{\mathrm{b}} \pm 30$ & $1032.00^{\mathrm{a}} \pm 32.3$ & $783.33^{\mathrm{c}} \pm 2^{7.5}$ \\
\hline IBA Antibody titer & $470.00^{\mathrm{d}} \pm 12.14$ & $873.33^{\mathrm{b}} \pm 20$ & $1030.33^{\mathrm{a}} \pm 22.77$ & $770.00^{\mathrm{c}} \pm 17.6$ \\
\hline
\end{tabular}

Mean values with in the same row which have different superscriptes, were significantly different $(\mathrm{P}<0.05)$ 
Table 4. data showing economics of various treatments

\begin{tabular}{|c|c|c|c|c|}
\hline Parameters & A & B & $\mathrm{C}$ & D \\
\hline Cost / chick (Rs.) & 12.00 & 12.00 & 12.00 & 12.00 \\
\hline Total feed consumed/ bird(kg) & 3.48 & 3.47 & 3.63 & 3.53 \\
\hline Feed cost/ kg (Rs.) & 13.5 & 13.5 & 13.5 & 13.5 \\
\hline Feed cost/ bird (Rs.) & 46.98 & 46.84 & 49.00 & 47.65 \\
\hline $\begin{array}{l}\text { * Miscellaneous charges/ } \\
\text { bird(Rs.) }\end{array}$ & 10.00 & 10.00 & 10.00 & 10.00 \\
\hline Total cost/ bird (Rs.) & 68.98 & 68.84 & 71.00 & 69.65 \\
\hline Average live weight (kg) & 1.65 & 1.78 & 1.85 & 1.73 \\
\hline Sale price/ kg(Rs.) & 42 & 42 & 42 & 42 \\
\hline Sale price/ bird(Rs.) & 69.3 & 74.76 & 77.7 & 72.66 \\
\hline Net profit (Rs.) & 0.32 & 5.92 & 6.7 & 3.01 \\
\hline
\end{tabular}

\section{Discussion}

\section{Performance}

Supplementation of herbal growth promoters in broilers ration significantly improved the weight gain of the birds. Similar findings are reported by Samanta and Dey (1991) and Meraj (1998) that supplementation of garlic powder improved the weight gain of broilers and Japanese quails, respectively $[24,19]$. The improvement in weiht gain might be due to inhibition in growth of pathogenic bacteria such as Staphylococcus aureus and Escherichia coli [13]. Chicory as a herbal growth promoters in broiler ration significantly improved the weight gain [25,22]. Similarly, Guler et al. (2003) observed higher weight gain in japanes quails fed Coriandrum sativum seeds [11]. Positive effect of turmeric and Moringa oliefera leaf extract as herbal growth promoter on weight gain of broiler was also observed [2]. Contrary to the finding of the present study Bolukbasi et al. (2006) and Soliman et al. (1999) reported a non-significant effect of herbal extracts on weight gain of broilers $[5,26]$ however difference in the results might be due to the different products used as herbal growth promoter.

Herbal growth promoters in the ration improved the feed comsumption of broiler. The result are in line with the finding of soliman et al. (1999) who observed that inclusion of the natural herbal growth promoters in broiler ration did not improve feed comsumption [26]. The result also coincide with the findings of El-Sheikh et al. (1998), Guler et al. (2006) who reported that feed consumption of the birds remained unaffected due to dietary inclusion of herbal growth promoter, kalongi [9]. Similarly, Samanta and Dey (1991) and Bozkurt et al. (2012) observed nonsignificant difference in feed intake by addition of garlic in the ration of Japanese quails and hebal oils in layers respectively $[24,6]$. In contrast to our finding, Siddig and Abdelati (2001) reported significant effect of Chicory extract on feed consumption of broiler ration [25]. Similar result have also been reported by Osman and Barody (1999) in broilers [22]. Supplementation of the herbal growth promoters exhibited a significant effect on the feed conversion ratio of the broilers.
Similarly Molla et al. (2012) reported that herbal supplemetation in diet of broilers increase production without adverse effects on chicken health [20]

The result are in line with the finding of Osman and Barody (1999), Siddig and Abdelati (2001), Ihsan (2003) and Ahmad (2005) who observed a significant effect of kalongi on feed conversion ratio in broiler [22,25,1]. The improvement in feed conversion ratio of the birds might be due to suppressing of growth of intestinal bacteria such as Staphylococcus aureus and Escherichia coli (Hanafy and Hatam, 1991) which caused increased absorption of nutrients leading to better feed conversion ration of the birds using rations supplemented with herbal growth promoters [13].

\section{Dressing Percentage and Organs Weight}

Supplementation of commercial herbal growth promoters did not exhibit any effect on the dressing percentage values of the borilers in this study. The result of the present study are in line with Samanta and Dey (1991) who reported that dietary inclusion of garlic did not affected dressing percentage in Japanese quiles [24]. Similar finding have been observed by Siddig and Abdelati (2001) and Ihsan (2003) in broilers fed Chicory leaves extract in their ration $[25,14]$. Dietary inclusion of commercial herbal growth promoters did not exert effect on the relative heart weight of the broiler use in this study. The result of the study are consistent with those observed by Soliman et al. (1999) and Ahmad (2005) who reported that the dietary inclusion of natural herbal growth promoters (garlic and kalongi) did not exhibit any effect on the relative heart weight of broilers $[26,1]$. Similar effects have been observed when garlic or kalongi were used in different trials on different species of birds. Siddige and Abdelati (2001) and Ihsan (2003) observed non-significant effect of garlic on relative weight of heart in broilers $[25,14]$.

Result of the study showed that supplementation of herbal growth promoters did not influence the relative liver weight, spleen weight, intestinal weight and gizzard weight of the broilers used in this study. These results are similar to those reported by Meraj (1998), Siddig and Abdelati (2001), Ihsan 
(2003) [19,25,14,]. However Ahmad (2005) observed that supplementation of garlic turmeric and kalongi exhibited a significant effect on relative intestinal weight of the broilers [1].

\section{Immune response against Necastle and infectious Bursal Diseases}

Dietary inclusion of herbal product in the broiler ration exhibited a significant effect on the immune response of birds against Necastle and infectious Bursal diseases. Similar findings are reperted by Soliman et al. (1999) and Ahmad (2005) that kalongi and garlic have significant effect on immune response of the broilers $[26,1]$. The exact reason of enhancement in immunity is not known. However it might due to the polysaccharides and ether extracts of herbs such as Nigella Sativa (kalongi) which have been found to cause hyperplasia of lymph-nodes and increase in the percentage of lymphocytes and neutrophills in blood. Meraj (1998) also reported significant boost in antibody titers against Newcastle and infectious Bursal diseases in broiler using garlic supplemented ration [19]. Similar results have been observed by Al-Sultan (2003) when turmeric was used as herbal growth promoter in the ration broilers [2].

\section{Economics of Production}

Use of various commercial herbal growth promoters in the ration exhibited an increase in the profit margin of broilers as compared to those using ration without supplementation. Dietary inclusion of commercial herbal growth promoters was found to be more profitable than control. Broilers reared on Respecine fetched maximum profit as compared to other groups.

Increase in the profit margin from the birds which were fed ration containing commercial herbal growth promoters might be attributed to the better efficiency of feed utilization, which results in more growth and better feed conversion ratio, ultimately leading to a higher profit margin the broilers reared on ration supplemented with commercial herbal products.

\section{Conclusion and Future Prospects}

Based upon the results of the study, in may be conclude that supplementation commercial herbal growth promoters in the broilers ration can improve efficiency of broiler's feed utilization resuting in to better growth results to efficient and economical production. These findings will help the poultry producers to save expenditure from pocket snatching prices of antibiotics, which they have to utilize for better health and growth of their birds. Above all, the use of commercial herbal growth promoters in the broilers rations will help in the production of organic broilers and save the health of mankind from ill effects of residual antibiotics present in the meat. However, determination of digestibility of various nutrients of the rations containing these herbal products, haemato-chemical profile and blood chemistry of the birds are the important question, which need to be addressed.

\section{REFRENCES}

[1] S. Ahmad. Comparative efficiency of garlic, turmeric and kalongi as growth promoter in broiler. M.Sc.(Hons.)Thesis, Department Poultry Sciences, University of Agriculture, Faisalabad, Pakistan, 2005.

[2] S.I.Al-Sultan. The effect of Curcuma longa (turmeric) on overall performance of broiler chickens. International Journal of Poultry Science., 2:354-53, 2003.

[3] M. Babu, K. Gajendran., F.R. Sheriff, G. Srinivasan. Crown Growfit ${ }^{\circledR}$ supplementation in broilers improved their performance. Ind. Poult. Rev. May 23: 27-28, 1992.

[4] Bentea, M., A. Sara, L. Panta, L. Clapa. The effect of enzymatic complex allzyme SSF and organic selenium on some growth and consumption indices of broiler turkey. Anim. Sci. Biotech. 43: 9-12, 2010.

[5] S. Bolukbasi, C. Erhan, M.K. and özkan, A. Effect of dietary thyme oil and vitamin $\mathrm{E}$ on growth, lipid oxidation, meat fatty acid composition and serum lipoproteins of broilers. S. Afr. J. Anim. Sci. 36:189-196, 2006.

[6] M. Bozkurt, K. Küçükyilmaz, M. Pamukçu, M. Çabuk, A. Alçiçek, and A. U. Çatli. Long-term effects of dietary supplementation with an essential oil mixture on the growth and laying performance of two layer strains. Italian Journal of Animal Science. 11( 5): 23-28, 2012.

[7] A. Buxton, G. Fraser. Animal Microbiology. Blackwell Sci. Pub., Oxford. 1st Ed. 2:526-528, 1977.

[8] G. Devegowda. Herbal medicines, an untapped treasure in poultry production. In: Proc. 20th World Poult. Congr. New Delhi, India, 1996.

[9] A.M.A. El-Sheikh, Amin, A.E., A.A. Khadiga. The effect of feeding different levels of Nigella sativa seeds on layer performance and egg quality characteristics. Sudan J. Vet. Sci. Anim. Husb. 37:121-128, 1998.

[10] T. K. Ghosh. Efficiency of liver herbal production counteracting aflatoxin on broiler birds. Indian Poultry Review 32 33-34, 1992.

[11] T. Guler, O. N. Ertas and M. Çiftçi, B. Dalkılıç. The Effect of cornidor seeds (Cornidor Sativum L. ) as diet ingredient on the Performance of japanese quail. South African J. of Anim. Sci. 19 (3) : 425-430, 2003.

[12] T. Guler, B. Dalkılıç, O. N. Ertas, M. Çiftçi. The Effect of Dietary Black Cumin Seeds (Nigella Sativa L.) on the Performance of BroilersAsian-Aust. J. Anim. Sci. 19 (3) : 425-430, 2006.

[13] M.S. Hanafy, M.E. Hatam. Studies on the anti-microbial activity of N. sativa seed (Black cumin). J. Ethnopharmacol., 34: 275-278, 1991.

[14] K. Ihsan. Effect of different levels of kalongi (N. sativa) seeds on the performance of broilers. M.Sc. (Hons.) Thesis, Department of Poultry Sciences, University of Agriculture, Faisalabad, Pakistan, 2003.

[15] M. Hyden. Protected acid additive. Feed Intl. 7: 14-16, 2000. 
[16] C. Kemp, M. Kenny. Feeding the modern broiler for more. International Hatchery Practice, 17: 11-13, 2003.

[17] M. Kral, M. L. Angelovicova, J. Tkacova, M. Kliment. Probiotic and acetic acid effect on broiler chickens performance. Scientific papers. Anim. Sci. Biotech. 44: $149-152,2011$.

[18] O. M. Kumar. Effect of Liv-52® syrup on broiler performance in North Eastern region, Ind. Poult. Rev. April 22: $37-38,1991$.

[19] I.C.A., Meraj. Effect of garlic and neem leaves supplementation on the performance of broiler chickens. M.Sc. Thesis, Department of Poultry Sciences, University of Agriculture, Faisalabad, Pakistan, 1998.

[20] M. R. Molla, M. M. Rahman, F. Akter, M. Mostofa. Effects of Nishyinda, black pepper and cinnamon extract as growth promoter in broilers. The Bangladesh Veterinarian (2012) 29(2) : $69-77,2012$.

[21] H. Nidaullah, F. R. Durrani, S. Ahmad, I. U. Jan and S. Gul. Aqueous extract from different medicinal plants as anticoccidial, growth promotive and Immunostimulant in broilers. J. Agric. Bio. Sci. 1: 53-59, 2010.

[22] A.M.A. Osman, EL-Barody, M.A.A.. Growth performance and immune response of broiler chickens as affected by rations density and Nigella sativa seeds. Supplementation. Egyptian Poultry Science 19:619-634, 1999.

[23] M. Z. Saima, U. Khan, M. A. Jabbar, A. Mehmud, M. M. Abbas and A. Mehmood. Effect of lysine supplementation in low protein diets on the performance of growing broilers. Pak. Vet. J. 30: 17-20, 2010.

[24] A.R. Samanta, A. Dey. Effect of feeding garlic (A. sativum Linn.) as a growth promoter in Japanese quails (C. coturnix japonica) and its influence on dressing parameters. Indian J. Poult. Sci., 26: 142-145, 1991.

[25] R.M. Siddig, and K. Abdelati. Effect of dietary vitamin A and N. ativa on broiler chicks' performance. In: Proc. of 10th Int. Conf. of Assoc. of Inst. for Trop. Vet. Med. Livestock. Community and Environment, Copenhegen, Denmark, 2001.

[26] A.Z.M. Soliman, A.A. Gahzalah, S.H. El-Samra, A.M. Atta and Z.M.A. Abdo. The synergetic effect of either black seed or garlic with fat on broiler performance and immunity. Egyptian J. Nutr. Feed, 2: 603-620. 1999.

[27] R.G.D. Steel, J.H. Torrie, D.A. Dickey. Principles and Procedures of Statistics: A Biometric Approach, 3rd edition. McGraw Hill Book Comp. Inc. New York, 1996.

[28] R. Subapriya, S. Nagini. Medicinal properties of neem leaves: A review, Curr. Med. Chem. Anticancer Agents. 5(2): 149-160, 2005. 